\title{
Economics of marketing and processing of Aonla in district Pratapgarh (U.P.)
}

\section{J. RAI, SHESH PRATAP SINGH AND ARUN KUMAR SINGH}

Received : 22.07.2017; Revised : 11.09.2017; Accepted : 25.09.2017

\begin{abstract}
The study was carried out in Sadar block of district Pratapgarh in Uttar Pradesh with thirty Aonla growers (18 marginal, 6 small and 16 big farmers ) selected randomly from six village of the selected block. One mandi and three processing units were also selected to study the economics of different Aonla products and marketing functionaries. The investigation revealed that on an average investment of Rs. 510950 was needed to establish an Aonla processing unit. The cost of Morabba preparation worked out to Rs. 5594.40 for one quintal of Aonla morabba while cost of one quintal of aonla pickle preparation came to Rs. 4998.85 and Rs. 6073.45 worked out for preparation of one quintal of aonla chutney. There were four marketing channels observed to dispose of the aonla produce. Channel IV was more common to dispose off aonla and aonla produce in the study area. The highest producers' share in consumers' rupee was achieved in channel I ( $98.5 \%)$ but only 10 per cent respondents followed this channel due to lack of demand in local. Channel III was second largest followed channel provide 60.5 per cent of the producers' share in consumers' rupee.
\end{abstract}

KEY WORDS : Processing, Marketing, Price spread, Producers' share in consumers' rupee

How to cite this paper : Rai, J., Singh, Shesh Pratap and Singh, Arun Kumar (2017). Economics of marketing and processing of Aonla in district Pratapgarh (U.P.). Internat. J. Com. \& Bus. Manage, 10(2) : 237-242, DOI: 10.15740/HAS/IJCBM/10.2/237-242.

\section{MEMBERS OF THE RESEARCH FORUM}

Correspondence to:

J. RAI, Department of Agricultural Economics and Statistics, C.S.A. University of Agriculture and Technology, KANPUR (U.P.) INDIA

Authors' affiliations:

SHESH PRATAP SINGH, Department of Agricultural Economics and Statistics, C.S.A. University of Agriculture and Technology, KANPUR (U.P.) INDIA

ARUN KUMAR SINGH, Krishi Vigyan Kendra, ETAWAH (U.P.) INDIA 